\section{Krasanka Majer Jurišić}

Hrvatski restauratorski zavod

Izvorni znanstveni rad / Original scientific paper

UDK / UDC: 725.1(497.5-3 Dalmacija)"14/17"

25. 7. 2013.

\title{
Stanovanje mletačkih upravitelja u Dalmaciji od 15. do 18. stoljeća
}

Ključne riječi: upravna arhitektura, kneževa palača, stambena arhitektura, Dalmacija, mletačka uprava, generalni providur Key words: Administrative architecture, the Rector's Palace, residential architecture, Dalmatia, Venetian rule, Provveditore generale

U radu su prikazani rezultati istraživanja kneževih palača Cresa, Krka, Raba, Paga, Šibenika, Zadra, Splita, Trogira, Hvara $i$ Korčule - gradskih središta u vrijeme mletačke uprave u Dalmaciji. Analiza prostornog rasporeda, tlocrtne sheme i vertikalne podjele unutar građevine, kao i oblikovanja pročelja pokazala je da se u slučaju ove vrste građevina susrećemo s nizom uzora. Te palače nastaju kombiniranjem postojećih modela privatne izgradnje, sodređenim modifikacijama s obzirom na funkcije. U njihovu oblikovanju jasno je vidljiva želja za pokazivanjem i izražavanjem mogućnosti i snage predstavnika mletačke uprave. Općenito govoreći, proizlazi da je tijekom 15. i 16. stoljeća prevladavalo uređenje postojećih srednjovjekovnih kneževih palača, ali i određen broj njihovih novih gradnji. U kasnijem razdoblju mletačke uprave u Dalmaciji, u 17. i 18. stoljeću, te se palače samo održavaju $i$ pregraduju.

Početkom mletačke vlasti na istočnojadranskoj obali, osim teritorijalnih promjena, uslijedile su i promjene $\mathrm{u}$ političkom i društvenom uređenju dotadašnjih gradskih komuna koje su kroz 14. stoljeće bile samostalne jezgre u strukturi cijele regije. ${ }^{1}$ Najznačajnije obilježje političkog preustroja koji se dogodio nakon dolaska Venecije u naše krajeve početkom 15. stoljeća su promjene u samostalnosti odlučivanja komunalnih vlasti i njihov način financiranja. Glavna tendencija mletačke uprave bila je snažna centralizacija posjeda i njihova podređenost potrebama i interesima Venecije. Tako je i sam sustav odlučivanja u važnim pitanjima uključivao prvenstvo središnje vlasti koja je redovno bila izvještavana o događanjima i promjenama u svim pokrajinama.

$\mathrm{Na}$ čelu mletačke uprave u Dalmaciji bio je generalni providur sa sjedištem u Zadru. Njega je imenovao Senat i to isprva s mandatom na dvije, a poslije na tri godine službe, sa svim upravnim, sudskim i vojnim ovlastima. Providuru su izravno bili odgovorni knezovi čija je uloga bila predstavljanje i zastupanje mletačke vlasti u dalmatinskim gradovima.
Ti su predstavnici imali široke ovlasti, no na relativno malom teritoriju. Brinuli su se o cjelokupnom životu komune i njezine okolice, a u djelokrug njihove nadležnosti spadali su svi poslovi koji su se ticali povjerenog im područja. Knezovi su osim upravne imali i vojne ovlasti, što je u nekim slučajevima bilo vidljivo i iz njihova naziva. Tako je u Cresu, Krku, Rabu i Pagu mletački predstavnik nosio naziv knez, dok se u Šibeniku, Trogiru, Splitu, Hvaru i Korčuli zvao knez-kapetan. ${ }^{2}$ Jedino su u Zadru civilna i vojna vlast bile razdvojene i dvije su osobe dijelile upravnu odgovornost. Neki od njih imali su i svoje zamjenike i pomoćnike koji su preuzimali određene poslove, primjerice za gospodarska i financijska pitanja pomagali su im kamerlenzi, rizničari. Iz svojih osobnih sredstava svaki je knez plaćao i određeni broj sluga i pratilaca, konjušara i kuhara. Također valja spomenuti i instituciju notarijata koja je bila prilično važna u upravno-sudskoj strukturi mletačke vlasti, a izravno je bila u službi kneza i financirana iz njegove blagajne.

Posljednje stoljeće mletačke vladavine u Dalmaciji obilježeno je reorganizacijom, čime je dobivena zamršena 


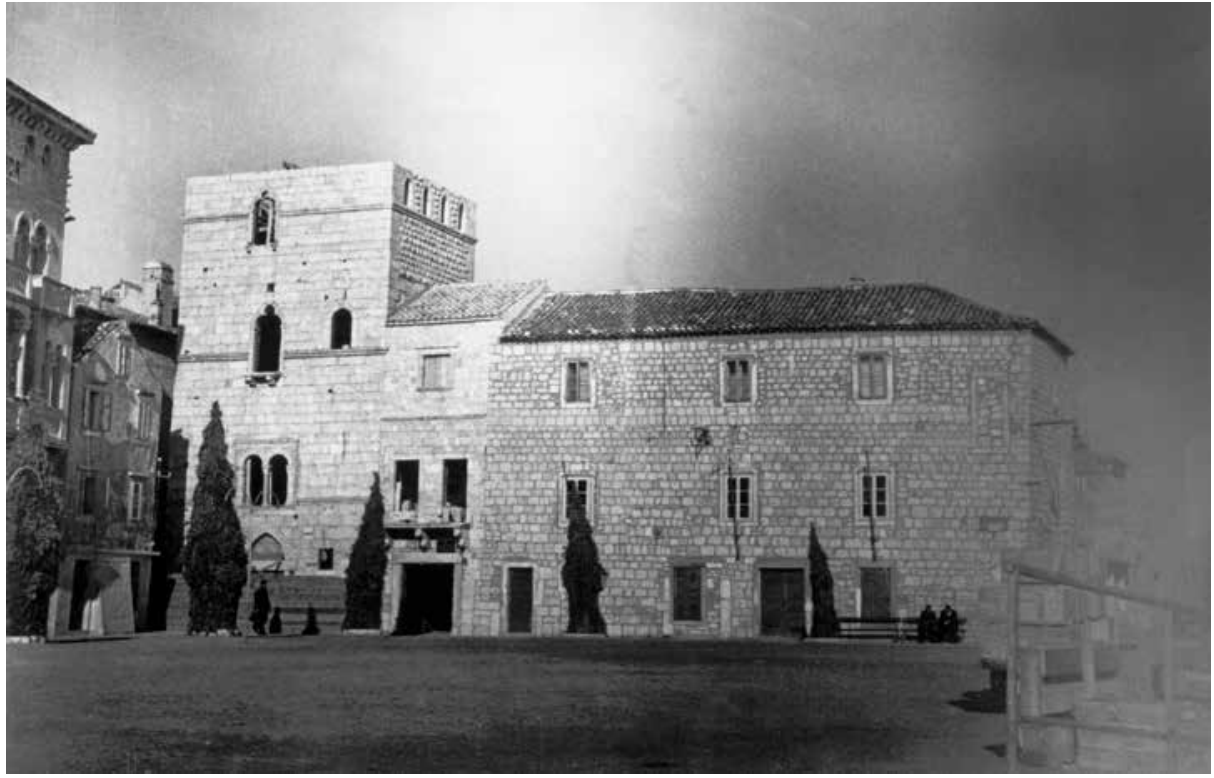

1. Rab, kneževa palača, Fotodokumentacija Konzervatorskog zavoda u Rijeci (foto: Šerak, 1954.) / The Rector's Palace, Rab, Rijeka Conservation Office, 1954

hijerarhija upravno-vojne podjele što je zapravo pridonijelo neučinkovitom načinu odlučivanja i kočilo gotovo ikakav razvoj lokalnih upravnih centara, podređenih pokrajinskoj centralnoj vlasti u Zadru, i stagnacijom koja je proizašla dijelom iz prekida daljnjega teritorijalnog širenja mletačkih područja, potom zbog sve lošijega gospodarskog stanja u državi, a time i slabljenja mletačkoga političkog utjecaja u tadašnja događanja u Europi.

Mletački upravitelji, knezovi, koji su organizirali upravu u dalmatinskim gradskim središtima živjeli su u javnim palačama: ${ }^{3}$ u većini slučajeva to su bile palače u kojoj su i knezovi i gradska vijeća obavljali i svoje dnevne poslove, ${ }^{4}$ no, iako rjeđe, knezovi su imali i zasebne palače namijenjene isključivo njihovu stanovanju, kao što je to bilo na Krku, Korčuli i u Splitu.

Neke od tih palača sagrađene su još u srednjem vijeku, a nova ih je vlast samo nastavila koristiti. Među najstarijim kneževim palačama u Dalmaciji su rapska (sl. 1), hvarska, zadarska, trogirska i šibenska iz 13. stoljeća, te korčulanska s početka 14. stoljeća. Srednjovjekovna splitska ${ }^{5}$ kneževa palača, izgrađena u 13. stoljeću na Peristilu, formiranjem novoga gradskog javnog trga izgubila je svoju funkciju, a za potrebe stanovanja kneza i za potrebe funkcioniranja upravnog i administrativnog aparata sagrađen je novi građevinski kompleks. Točne godine gradnji ovih palača najčešće nam nisu poznate, tako da o njihovoj dataciji zaključujemo posredno, prema stilskim i graditeljskim odlikama te prema najranijem spomenu u arhivskim spisima. ${ }^{6}$

Druge su pak kneževe palače građene nešto poslije, nakon dolaska Venecije u dalmatinske gradove. To su redom palače u gradskim središtima koja ranije, u srednjem vijeku, nisu imala takvu vrstu građevina jer tamo ili nije postojala potreba za trajnim smještajem tijela uprave i stanom za kneza, ili je, kao u Krku, postojalo htijenje Venecije da jasno razgraniči dotadašnju vlast od nove, a tako i njezin smještaj. Primjerice u Cresu, koji tek nakon 1450 . godine postaje novo službeno upravno središte otoka, dolaskom Venecije počinje formiranje novoga glavnog gradskog trga s objektima javne namjene: javnom (pretorskom) palačom, gradskom ložom, gradskim tornjem sa satom, zgradom fontika i crkvom sv. Ivana. ${ }^{7}$ I u Krku se krajem 15. stoljeća gradi nova javna palača, poznata kao providurova. ${ }^{8}$ Ta je izgradnja bila dio velikoga urbanističkog zahvata kojim je mletački upravitelj Antonio Vinciguerra želio modernizirati izgled i funkcije grada, koncentrirajući se najprije na sjeverozapadni dio gradske jezgre i veliki javni trg uz glavna gradska vrata, a potom i na jugoistočni dio, uz same gradske zidine, gdje je sagrađena i palača. Treći primjer nove izgradnje je kneževa palača u Pagu, sagrađena u 15. stoljeću ${ }^{9}$ na glavnom gradskom trgu. Palače u Cresu i Pagu bile su i palače kneza, ali i zgrade u kojma je bila dvorana za sjednice gradskog vijeća, te još neke prostorije administrativne namjene. Nasuprot toga, providurova palača u Krku uistinu je bila zgrada namijenjena stanovanju mletačkog upravitelja i uz nju su zasebno bile dograđene kuće za gradskog nadglednika, kamerlenga, prostor javne pisarnice i sl., dok je vijećnica, barem od 16. stoljeća, bila na drugoj strani grada, na trgu uz glavna gradska vrata.

Vrijeme nakon 1600. godine obilježila je tek izgradnja kompleksa palače generalnog providura ${ }^{10} \mathrm{u}$ Zadru. U tom razdoblju ostala gradska središta u Dalmaciji samo uređuju svoje palače sukladno svakodnevnim potrebama funkcioniranja državnog aparata i dakako s vrlo ograničenim sredstvima. Zaseban slučaj su i palače novih upravnih centara, na područjima osvojenim u ratovima s Turcima, gdje je bilo nužno oformiti i urediti urede državnih službenika. Primjerice, u Makarskoj koja je Mletačkoj Republici pripojena 1684. godine, zatim u Kninu (oslobođen od Turaka 1688. godine) te u Imotskom (pod vlašću Venecije od 1717. godine), po dolasku mletačke uprave uspostavljen je njezin administrativni aparat. Državni predstavnik i njegovi službenici dobili su prostor za život i redovno funkcioniranje, i to najčešće u privatnim kućama koje su prilagođene 
novoj namjeni. ${ }^{11}$ Nažalost, uslijed lošeg stanja i neredovitog održavanja palača u kojima su živjeli i radili mletački upravitelji u tom je razdoblju čak i u gradovima, Cresu, Krku, Pagu i Šibeniku, postojala redovita praksa iznajmljivanja privatnih kuća. ${ }^{12}$

\section{Tlocrtna organizacija i namjene prostorija}

Tlocrtne odlike kneževih palača pokazuju neke sličnosti prema kojima ih možemo svrstati u određene skupine. ${ }^{13}$ Naravno, vrlo je teško sa sigurnošću govoriti o njihovu izvornom izgledu ili izgledu u razdoblju između 15. i 18. stoljeća jer su nakon toga uslijedile brojne pregradnje i prilagodbe za potrebe novih korisnika.

Osnovni L-tlocrt pokazuju paška kneževa palača, sklop komunalne i kneževa palače u Splitu i palača u Cresu. Dok je na primjeru paške palače zgrada L-tlocrta nastala u jednom dahu, zamišljena kao objekt upravo takvog tlocrta, u Cresu i Splitu takav je tlocrt rezultat postupnog spajanja više zgrada različitih volumena u jednu cjelinu. Još je jedna karakteristika zajednička ovdje spomenutim palačama, to je dvorište, kao zasebna cjelina nadodano uz postojeće objekte.

Dvorište ima i druga grupa građevina, višekrilne zgrade, koje svoje volumene organiziraju upravo oko te središnje prostorne jezgre. Takvu tlocrtnu dispoziciju pokazuju palače u Rabu, Zadru, Šibeniku i Trogiru. To su trokrilne i četverokrilne građevine, dograđivane kroz više stoljeća čime se dakako mijenjao njihov karakter. Šibenska je palača primjerice nastala iz prvotnog L-tlocrta uređenjem i dogradnjom pojedinih dijelova u 15. stoljeću.

Kao objekt pravokutnog tlocrta javlja se knežev dvor u Korčuli, no, iako je to građevina samostalnog volumena, ostvarena je čvrsta komunikacija prema gradskim zidinama i

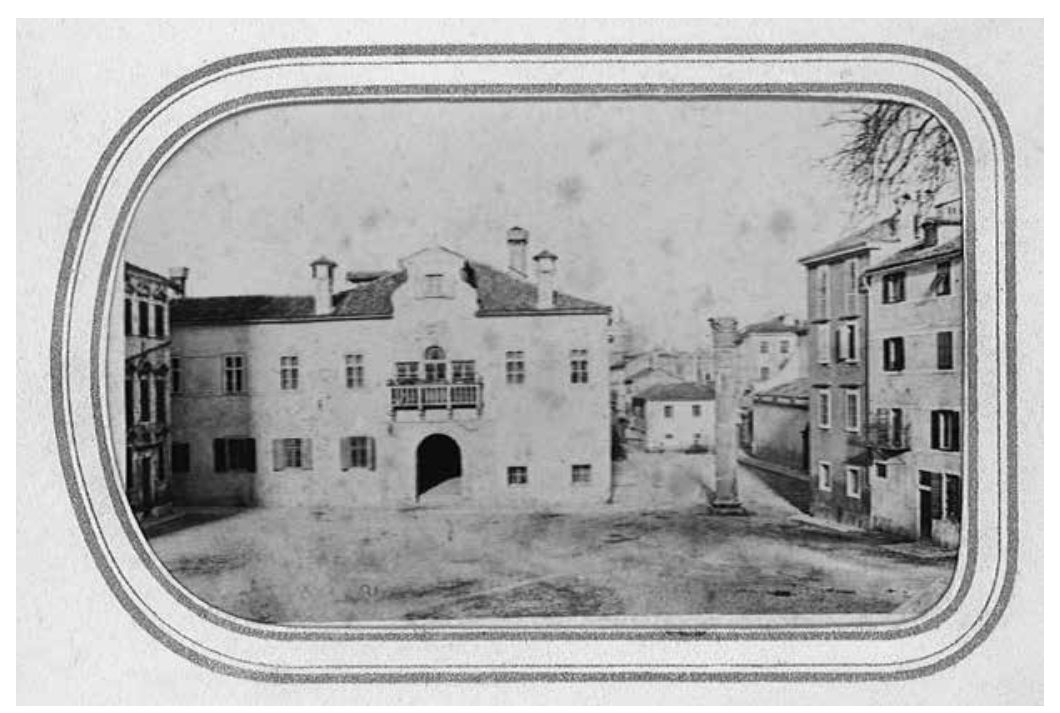

kulama koje tako postaju njegov gotovo integralni dio. Dvor je dvorištima i prolazima bio povezan i s korčulanskom vijećnicom.

Zasebno pak možemo razmatrati hvarski knežev dvor te providurovu palaču u Zadru (sl. 2), objekte koji ne pokazuju nikakve zajedničke odlike s drugim spomenutim primjerima javnih palača. Knežev dvor u Hvaru nepravilan je konglomerat više objekata različitih visina i tlocrta, povezanih međusobno u jednu cjelinu, no istodobno ostajući jasno razgraničenih volumena, a zadarska je providurova palača složen građevinski kompleks koji zaprema veličinu zatvorenoga stambenog bloka, organiziranog oko više unutrašnjih dvorišta.

O namjeni pojedinih prostorija možemo govoriti temeljem sačuvanih nacrta ili arhivskih spisa. ${ }^{14}$ Tako primjerice o kneževu dvoru u Korčuli saznajemo prema sačuvanim nacrtima iz 19. stoljeća koji bilježe stanje tek nakon kraja mletačke uprave, no još uvijek su nam dosta vjeran pokazatelj. ${ }^{15}$ Najiscrpnije podatke donosi nacrt koji je izradio Josip Zmajić, a prikazuje tlocrt prizemlja i prvog kata cijelog kompleksa kneževa dvora, uključujući i dio gradskih zidina i kula (sl. 3). Nacrt je potpisan, ima mjerilo, a u donjem desnom kutu papira stoje tekst i legenda kojom se objašnjavaju funkcije pojedinih prostorija. ${ }^{16} \mathrm{U}$ prizemnom dijelu naznačene su soba za drva (a), spremišta (b), velika zidana cisterna i djelomično iznad nje vrt (upisano izravno u nacrt), a na prvom su katu ulazni prostor (1), velika dvorana (2), soba za posluživanje (3), kuhinja (4), blagovaonica (5), mjesto za odlaganje (6), sobe za služinčad (7), soba koja je služila knezu (8), te kneževa spavaća (10) i dnevna (radna) soba (9). Prema nekim navodima moguće je da su u nekom razdoblju na prvom katu bile i dvije dvorane, od toga jedna sa stupovima i kaminom, a jedna jednostavna, ${ }^{17}$ a zabilježeno je da je u sklopu dvora bila i kapelica, nažalost srušena u vrijeme francuske uprave. ${ }^{18}$

O rasporedu prostorija u šibenskoj kneževoj palači najviše pak saznajemo iz njezina opisa $u$ Generalnom katastru ${ }^{19}$ koji je sastavio mletački javni inženjer Gian Nicolò Nachich i nacrta ${ }^{20}$ koje je desetak godina prije, 1788. godine, napravio inženjer F. Zavoreo. U prizemlju istočnog krila bile su prostorije gospodarske namjene, sa zasebnim ulazom iz ulice koja vodi kroz gradska vrata Porta del Palazzo. Na katu istočnog krila također su bile prostorije uporabnih funkcija: kuhinja, ostava i spremište, a do

2. Fotografija baroknog pročelja providurove palače u Zadru (Znanstvena knjižnica Zadar, Marasovićev album) / Photo of Baroque front of The Rector's Palace in Zadar, Zadar Scientific

Library, Marasović album 


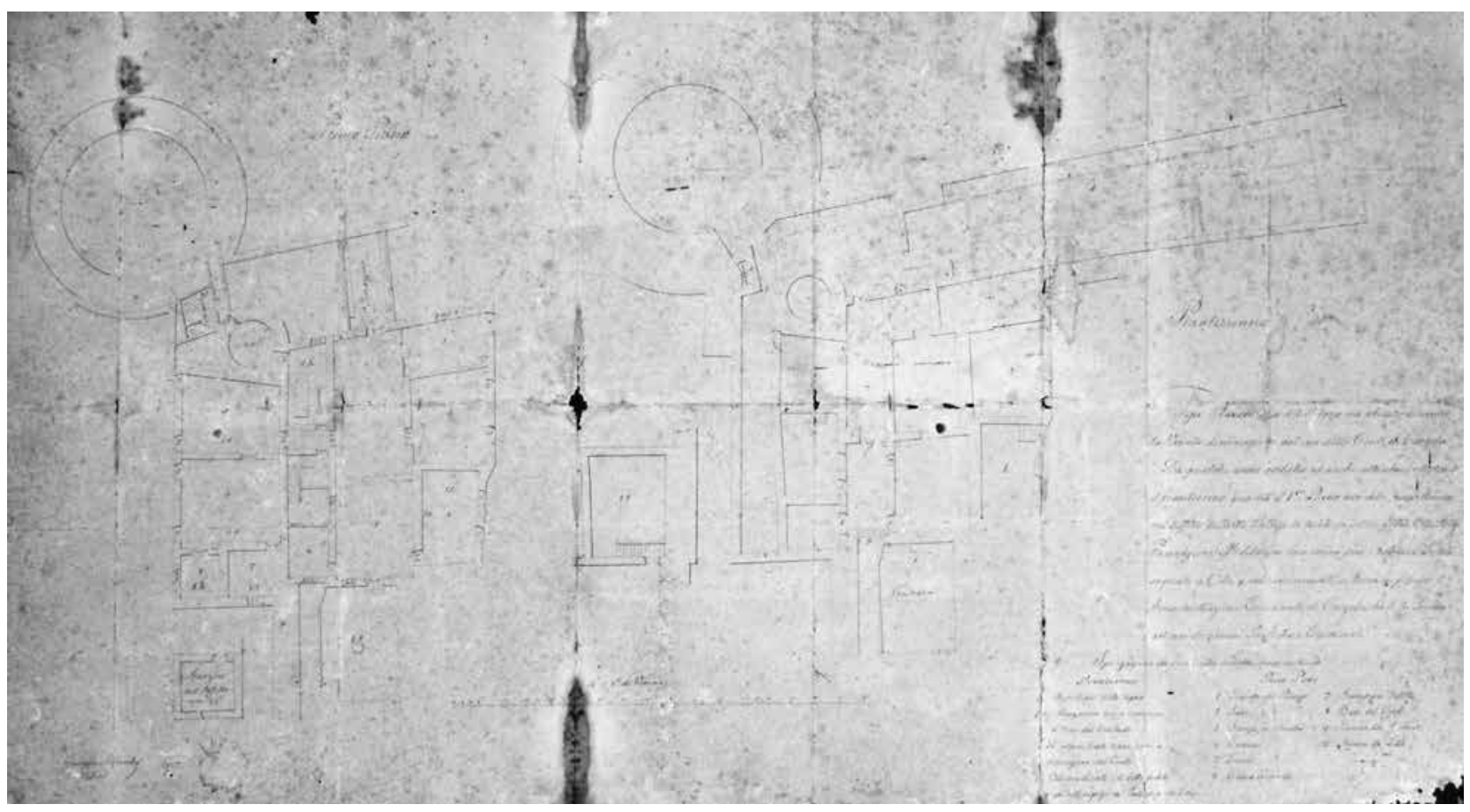

3. Tlocrt kneževa dvora u Korčuli, crtao J. Zmajić, 19. stoljeće, Gradski muzej Korčula (presnimila i ustupila: M. Hajdić) / Ground-plan of The Rector's Palace in Korčula. Drawing by J. Zmajić, 19th century, Korčula Municipal Museum, a copy obtained courtesy of M. Hajdić

njih se dolazilo drvenim stubištem ${ }^{21}$ kojim je vertikalna komunikacija ostvarivana na još nekoliko mjesta unutar palače. Iz ovog se dijela kroz mali hodnik dolazilo u južno krilo namijenjeno privatnim potrebama kneza. Tu su redom od istoka prema zapadu: spavaća soba, dnevni boravak, reprezentativna dvorana u kojoj se sastajalo gradsko vijeće s malom kapelom i primaća soba iz koje se ulazilo u kneževu kulu gdje je na toj etaži bio salon.

Uspoređujući ova dva ali i ostale primjere kneževih palača, mogu se uočiti neke sličnosti. Kapelica se u kneževim palačama nalazila redovito (Hvar, Korčula, Pag, Krk, Rab, Trogir). U nekim je slučajevima bila smještena u zasebnu prostoriju i imala je još i sakristiju, dok je ponekad njezina izvedba vrlo skromna, tek kao dio veće prostorije gdje je postavljen kućni oltar.

Neke palače, poput šibenske, imaju zasebna krila gospodarske namjene u kojima su bila razna skladišta i pomoćni prostori te kuhinja (Trogir, Zadar), a kuhinja je bila smještena i u prizemlju (Cres) ili na prvom katu uz još neke radne prostorije iznad kojih je bilo reprezentativno stanovanje (Hvar), te čak i zajedno s ostalim kneževim prostorijama (primjerice Korčula).

Ako su kneževe palače ujedno imale i upravnu i administrativnu a ne samo stambenu namjenu, dvorane za vijećanje najčešće su bile smještene na prvom, reprezentativnom katu (Rab, Trogir, Šibenik i Pag), a imamo i slučajeve kada se dvorana seli na drugi kat, kao u Cresu ili Hvaru. Administrativni prostori, kancelarija, blagajna, razni uredi i općinska pisarnica najčešće se smještaju u prizemlju, uz ulaz u palaču, a mogu imati i svoje vlastite ulaze s trga. Zatvorske pak prostorije uvijek su u blizini ili su u sklopu kneževe palače. Tako je u Cresu zatvor smješten u zasebnoj prigradnji uz palaču, u Hvaru se nalazi u jednoj od kula s time da su ćelije za teške zatvorenike i ćelije za lakše zatvorenike i prijestupnike bile jasno razdvojene, u Korčuli i Šibeniku također je jedna kula bila namijenjena za tamnice, u Krku su se tamnice nalazile ispod razine zemlje, pod putom koji je povezivao providurovu palaču s pisarnicom, a u Zadru u prizemlju palače, uz dvorište.

Dvorišta palača najčešće su imala otvoreni trijem (Trogir, Zadar, Cres, Korčula, Pag), cisternu i bunarsku krunu, a ponekad i vrt (Zadar, Korčula). U dvorištu su se nalazila i kamena stubišta za gornje etaže (Trogir, Rab, Cres), ili su ta stubišta bila smještena uz vanjsko pročelje palače (Split), a u nekim su slučajevima formirana i unutar volumena zgrade (Zadar, Korčula). Također nisu bila rijetkost ni drvena manja stubišta kojima su međusobno povezivane ne toliko reprezentativne prostorije različitih etaža.

Neke od palača imale su i štale, to jest konjušnice i prostor za uzgoj životinja, kao primjerice Zadar, Trogir i Šibenik. Gospodarsku namjenu (skladišta, radionice i dućani) imale su i prostorije davane u najam od čijeg je prihoda dodatno punjena općinska blagajna (Split, prizemlje palače u Cresu).

Već je rečeno da providurova palača u Zadru odskače od ostalih javnih palača. Njezine su prostorije organizirane $u$ složenom sklopu oko nekoliko unutrašnjih dvorišta, dok su 
pojedina krila i zasebno formirani dijelovi zgrada međusobno bili povezani nizom kamenih i drvenih stuba.

\section{Oblikovanje vanjštine}

Reprezentativnost nekog prostora, odnosno građevine, najvećem broju osoba vidliiva je upravo kroz oblikovanje vanjštine. Ta je činjenica prihvaćena i na primjeru javnih palača koje svojim vanjskim izgledom i žele polučiti jaki utisak divljenja, no ujedno i određenu dozu strahopoštovanja kod građana. Dakako, vrlo čest element na pročeljima nakon dolaska nove uprave je kameni reljef svetog Marka ${ }^{22}$ koji mletačka vlast postavlja kao jasan biljeg svoje prisutnosti.

Također valja uzeti u obzir i vrijeme kada se građevina uređuje, preuzimajući

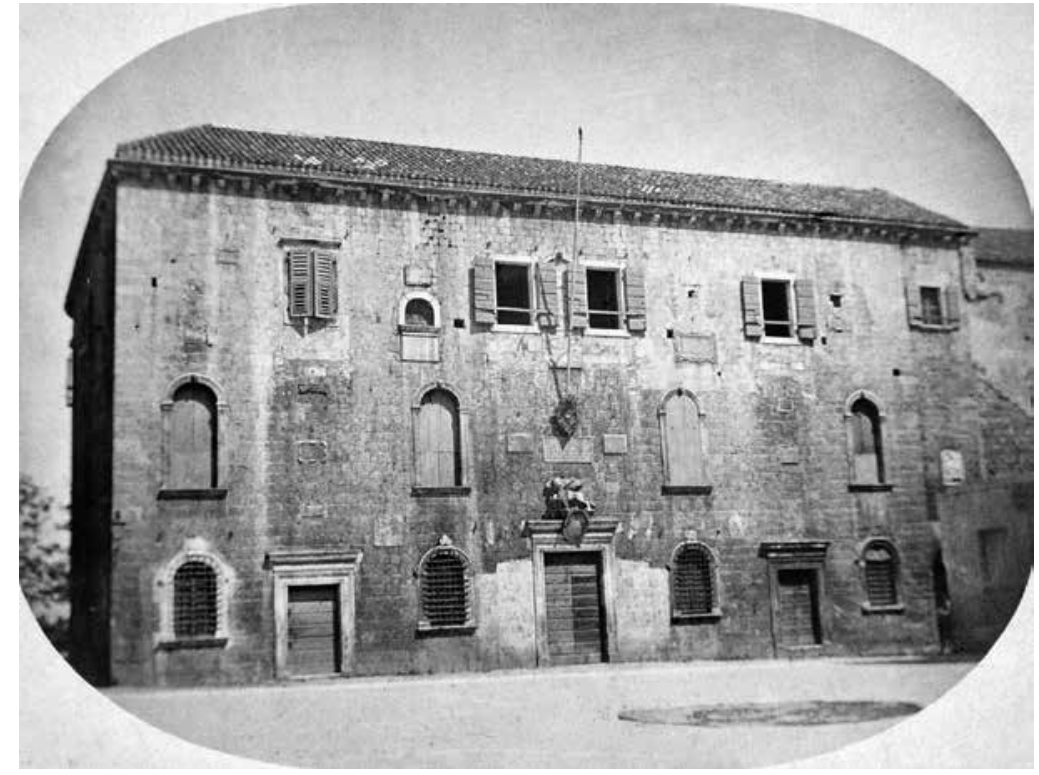

5. Fotografija trogirske kneževe palače, 19. stoljeće, Muzej grada Trogira (presnimila i ustupila: D. Radić) / Photo of The Rector's Palace in Trogir, in the 19th c, Trogir Municipal Museum, a copy obtained courtesy of D. Radić modele koji u to doba postoje u arhitektonskoj praksi. Pročelja kneževih palača najčešće imaju više kasnosrednjovjekovni izričaj i gotovo da nema primjera zrelih ili pak kasnorenesansnih elemenata. ${ }^{23}$

Šibenska kneževa palača zatvorenog je volumena i njezini su otvori prilično skromni (sl. 4). Dakako, rezultat je to i činjenice da je svojim cijelim južnim pročeljem ta palača bila dijelom obrambenog gradskog zida pa njezino ukrašavanje i rastvaranje kićenim i velikim prozorima i nije bilo odviše moguće. Više je pažnje posvećeno pročelju okrenutom prema svetištu katedrale gdje je i ulaz u palaču. Tu su dvoja vrata s okvirima istovrsnih profila, a iznad svakih je natpis pisan rimskom kapitalom. Između vrata je polukružno zaključena niša u kojoj je na postolju postavljena skulptura muškarca srednje dobi, obučenog u jednostavnu dugačku halju.

$\mathrm{U}$ vrijeme mletačke uprave glavno pročelje trogirske palače imalo je drugačiju ritmičku podjelu otvora prizemlja, prvog i drugog kata od one današnje (sl. 5). U prizemlju su bili polukružni prozori koji se datiraju na prijelaz iz 15. u 16. stoljeće i pripisuju radionici Nikole Firentinca, ${ }^{24}$ na prvom su katu bili izduženiji prozori s kamenim glavama koje je izgledno radio Trifun Bokanić, ${ }^{25}$ dok su na dru-

4. Šibenik, pogled na južno pročelje Kneževe palače, 2010. / Šibenik, view of the south front of The Rector's Palace, 2010 gom katu bili obični prozori četvrtastog oblika. Cjelokupna ploha pročelja nije imala klasičnu renesansnu ortogonalnu mrežu, kao ni ujednačen ritam otvora (vertikalne osi prozora prizemlja, prvog i drugog kata nisu se poklapale, nego su prozori postavljeni naizmjence, a isto tako nije bilo ni jednake horizontalne podjele, jer, osim što su izostavljeni razdjelni vijenci, ni visine katova nisu bile jednake).

Osim vrsno klesanih romaničkih bifora na južnom krilu rapske kneževe palače koje su rastvarale zid svečane dvorane u prvom katu i romaničko-gotičkog portala kule, ${ }^{26}$ na istoj palači javlja se i vrlo zanimljivo oblikovanje kamenog balkona. Taj balkon nalazi se nad portalom istočnog krila i

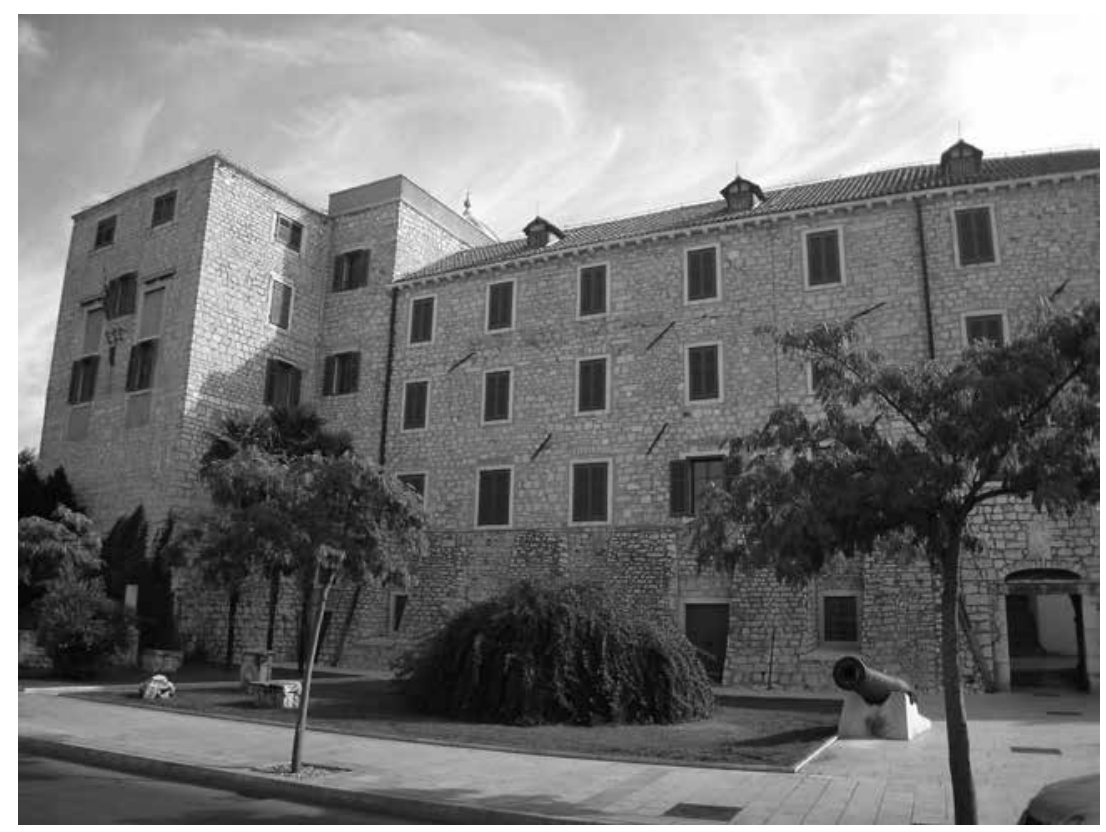


dio je uređenja palače u 15. stoljeću ( $\mathrm{u}$ to vrijeme izvedene su i gotičke monofore i renesansa bifora na kuli, te monofore na drugom katu južnog krila). Postavljen je na tri dvostruke konzole od kojih svaka prikazuje različito oblikovanu lavlju glavu. ${ }^{27}$ Iznad svake od konzola po jedan je stub balustrade, a između njih su stupići povezani polukružnim lukovima. Na uglovima balustrade postavljene su dvije sjedeće klesane lavlje figure.

Na kneževoj palači u Pagu možemo izdvojiti dva dekorativna elementa po kojima je njezino pročelje posebno zanimljivo. To je jedan natprozornik, ugrađen na pročelju koje gleda na gradski trg, na kojem je izveden motiv plitke izdužene školjke koja završava rozetama, ${ }^{28}$ te dvorišni portal palače iz 1467. godine. Nadvratnik portala ukrašen je reljefom s prikazom primorskog pejzaža s utvrđenim gradovima i brodovima u sredini kojeg je bio lav svetog Marka, a u luneti iznad njega je kameni klesani grb između dva putta. Oko mogućeg autora ovoga vrsnog klesarskog djela vodila se rasprava, $i$ iako se pretpostavljalo da je to djelo samog Jurja Dalmatinca, ipak danas prevladava mišljenje da je portal rad Ivana Pribislavića. ${ }^{29}$

I na kraju, karakteristično za glavno pročelje kneževe palače u Cresu je naglašena središnja os, formirana triforom i malim balkonom u drugom katu ispod kojeg je bio pozlaćeni kameni reljef svetog Marka. Oko reljefa bilo je ugrađeno još nekoliko kamenih ploča i štitova. Prvi i drugi kat bili su rastvoreni s ukupno pet prozorskih osi. Otvori u prizemlju su bili jednostavni i u jednom dijelu slijedili su ritam gornjih etaža, no njihov je raspored bio prilagođen namjenama prizemnih prostorija

Nadalje, u drugoj polovini trajanja mletačke uprave, kroz 17. i 18. stoljeće, nema nekih brojnih ni izrazito vidljivih napora da se dekorativnim leksikom na pročeljima palača prate promjene u stilu. Najčešće je riječ o dodacima na postojeće, i to u vidu novih klesanih grbova, natpisa ili elemenata poput stupova kamene ograde.

\section{Unutrašnja oprema}

Opremanje prostorija palače zasigurno je bilo mnogo izdašnije nego što mi danas možemo iščitati temeljem sačuvanih primjera, ili putem zapisa. U tekstu koji slijedi dani su samo neki primjeri opreme unutrašnjosti javnih palača, no valja vjerovati da su oni bili brojni i daleko raznovrsniji.

Godine 1532. poznati hvarski humanist Vinko Pribojević u svojem govoru u crkvi sv. Marka spominje i kneževu palaču o kojoj kaže da je prekrasna i da je čuvaju veličanstvene kule. Nadalje, njegova se oduševljenost tom građevinom očituje u opisu: u palači je prostrana vijećnica, velike prostrane sale, ugodni hodnici, radne sobe za suce (i to zasebno ljetne i zimske), veliko dvorište s dva bunara, i »sve iznutra i izvana uređeno velikim troškom i kraljevskim (kako se kaže) sjajem«. Za istu palaču postoji i podatak da je cijela bila ukrašena freskama. ${ }^{30}$

Vrlo se često palače opremaju i klesanim elementima. Tako, primjerice, korčulanski klesar i graditelj Grgur Dujmov krajem 16. stoljeća obrađuje kamen za vrata nove tamnice u kneževu dvoru, a izradio je i grb za svod prolaza kojim se iz kule dolazilo u dvor. ${ }^{31} \mathrm{U}$ palači u Rabu ostao je sačuvan renesansni ulomak jednog kamina s kraja 15. stoljeća. ${ }^{32}$ Ulomak je vrlo bogato ukrašen i pokazuje odlike renesansnog stila. Jedan od primjera opreme je i klesana kruna bunara koju je imala svaka palača s dvorištem. Neke su krune još gotičkog izraza, primjerice kruna u dvorištu trogirske palače ${ }^{33} \mathrm{~s}$ grbom kneza Barbariga i prikazom krilatoga mletačkog lava, ili s druge strane grlo zdenca krčke providurove palače klesano 1557. u vrijeme krčkog providura Angela Gradeniga. ${ }^{34}$ To grlo ima šest kamenih vrsno klesanih ploča s mletačkim lavom, natpisima, festonima, štitovima i vrpcama. ${ }^{35}$ Postoji i zapis o cisterni na Cresu za koju je 1586. godine za njezino dovršenje potpisao ugovor s kamenorescem Jeronimom Taiapierom po cijeni od 35 dukata. Godinu poslije na istoj su palači izvedeni još neki klesarski radovi u dvorištu (novi kapiteli i stubovi za trijem te dijelovi kamenog stubišta) za koje je bio zadužen majstor Marko Soldatić. ${ }^{36}$

Gradnja i klesanje dvorišnog stubišta u Trogiru pripisuje se radionici Mateja Gojkovića, ${ }^{37}$ a istom se majstoru pripisuje i klesanje dekorativnih elemenata: glave muškarca na nosaču koji spaja dva luka stubišta te klesanje grba kneza Magdalena Contarinija iz 1428. godine, ugrađenog pod zadnjim lukom stubišta. ${ }^{38}$

Ako je kneževa palača imala i dvoranu za vijećanje, ona je bila namještana da zadovolji dvostruku funkciju: onu sposlovnu<, upravnu - smještaj određenog broja vijećnika i omogućavanje njihova rada tijekom sjednica, i onu drugu, 'zabavnu<, društvenu - ugošćivanje javnosti u mnogim prikladnim svečanostima. Obje su funkcije zahtijevale prostor koji je reprezentativno opremljen dajući prisutnima vidljiv i opipljiv dokaz moći i ukusa predstavnika vlasti te lokalne zajednice. $^{39}$

Također se s obzirom na postojanje kapele u kneževim palačama može reći da je zasigurno u javnom inventaru bilo i svetih slika, crkvenog namještaja i uporabnih posvećenih predmeta. U jednoj vizitaciji kapele u providurovoj palači u Krku iz 16. stoljeća zabilježeno je: »... Odatle pođe u kapelu zapovjedničkog stožera presvijetloga providura. Utvrdi da ima dosta dobru oltarnu palu, smještenu na dva kamena podupirača, s dva svijećnjaka i pozlaćenim palijem, ali bez ručnika. ${ }^{40}$

Opisi izgleda prostorija u palačama u kojima su živjeli mletački upravitelji nalaze se i u Inventaru državnih zgrada s kraja 18. stoljeća. ${ }^{41}$ Vrlo sadržajan je opis palače generalnog providura u Zadru, ${ }^{42}$ a o zadarskoj kneževoj palači zapisano 
je da su stropovi u kneževoj primaćoj sobi te dvije njegove privatne prostorije bili ukrašeni štukom, a pod u jednoj od primaćih soba palače bio je prekriven terazzom. U istom je dokumentu zabilježen i jedan kamin. Prostor kapelice u toj palači, nažalost, nije detaljno opisan, ali je naznačeno da se na njezinu oltaru nalazila pala sv. Roka. Kapela u kneževoj palači u Šibeniku imala je na oltaru palu s motivom Gospe od Ružarija, a na antependiju je bila izložena slika Bogorodice.

\section{Privatna gradska palača i kneževa palača}

U dalmatinskim gradovima tijekom srednjeg vijeka naseljavaju se pripadnici različitih slojeva društva. Njihove su kuće odraz njihova imovinskog stanja i najčešće nisu služile samo za stanovanje nego su imale i gospodarsku funkciju, primjerice radionice, dućani, skladišta. Tako, gledajući prema namjeni, nastaje tip polivalentne kuće. Upravo je funkcionalna struktura jedan od glavnih elemenata kuće nastale u Veneciji i područjima pod mletačkom upravom tijekom 14. i 15. stoljeća. ${ }^{43}$ Te se različite funkcije jasno očituju i na pročelju kuće, pokazujući izborom i oblikovanjem otvora raspored unutrašnjeg prostora. Kod plemićkih kuća naglašava se primjerice etaža reprezentativnog stanovanja, piano nobile, koja se razlikuje po svom dekorativnom izrazu, visini, mjerilu, obliku i broju otvora. Ovi su elementi lako vidljivi i stoga se i većina istraživanja o stambenoj arhitekturi zadržava upravo na njima.

No, arhitektonska struktura je ono što uobičajeno daje polazište za određivanje pojedinoga građevinskog tipa. Nažalost, kod stambene arhitekture ranijih razdoblja ona često nestaje tijekom stoljeća i vrlo je teško govoriti o izvornim tlocrtnim rasporedima kuća. Također se prostorna organizacija transformira nešto sporije nego oblikovanje zidnog plašta i promjene ukrasnih elemenata i donekle kasni u svojoj primjeni gledajući karakteristike određenih stilskih razdoblja. Stoga, generalno gledajući, može se reći da u srednjem vijeku širom Europe nastaje internacionalni model koji je pratio urbani preporod zapada. Tako se i kod nas, na istočnoj obali Jadrana, u tom razdoblju prepoznaju dva osnovna tipa kuće: kuća jedinstvenog volumena i kuća komponirana od više volumena s distributivnim dvorištem. ${ }^{44}$ Ovaj drugi tip stanovanja zapravo je kuća koja ujedinjuje ranije samostalne objekte u cjelinu, služeći se središnjim zajedničkim dvorištem kao jezgrom preko koje se ostvaruje vertikalna komunikacija između katova, ali i horizontalna povezanost prostora.

Jedan od takvih primjera vrlo često je i javna palača, odnosno palača kneza. Kao reprezentativna javna građevina, smještena najčešće na glavnom trgu, ona je bila vidljivi uzor, a svojim izgledom i prostornim rasporedom zasigurno je i utjecala na privatnu gradnju. Isto tako, u njezinu se formiranju mogu prepoznati sličnosti s velikim plemićkim kućama smještenim unutar gradske jezgre i to u razvoju prostorne sheme ograničene veličinom parcele te zatečenom ranijom gradnjom. Ponavlja se struktura ujedinjavanja jednovolumenskih kuća, često različitih visina, najčešće upravo komunikacijom ostvarenom preko galerija u unutrašnjem dvorištu. Tako se primjerice formira trogirska kneževa palača, ${ }^{45}$ kneževa palača u Zadru ${ }^{46}$ ili pak palača u Cresu, s time da se u tom slučaju dvorište nalazi uz zgradu, a nije njezina prostorna jezgra. Spajanje različitih volumena u jedinstvenu cjelinu čitamo i kod komunalnog i kneževa kompleksa u Splitu. ${ }^{47}$ Zanimljiv je primjer i palača u Šibeniku koja u svojoj izgradnji svladava zajednički problem s drugim objektima u gradu, kosina terena na kojima se podižu i ostvarivanje komunikacije između različito visokih dijelova građevine. ${ }^{48}$

Raspored prostorija unutar velike gradske kuće bio je određen prije svega potrebama, no pokušavala se pratiti uobičajena shema mediteranske renesansne gradske palače: zatvoreno prizemlje (najčešće služi za trgovinu, skladišta ili pak gospodarske poslove), dvorište s trijemom (formirano uz palaču ili kao njezin središnji dio) do kojeg se dolazi kroz široki natkriti prolaz (andronu), prvi reprezentativan kat, drugi kat sa stambenim prostorijama te uz njih, ili u potkrovlju sobe za sluge i kuhinja. Javljaju se i primjeri korištenja kula u stambene svrhe kad one bivaju inkorporirane u postojeću obiteljsku kuću. ${ }^{49}$ Sve te karakteristike imaju i kneževe palače, s time da ako imaju i javnu funkciju, njihove se administrativne, sudske i upravne funkcije najčešće ostvaruju u 'gospodarskom` prizemlju privatne palače.

Podaci o uređenju plemićkih kuća, odnosno privatnih gradskih palača u vremenu od 15. do 18. stoljeća iscrpniji su od onih koji su poznati za kneževe palače. ${ }^{50}$ Neki od ukrasnih i uporabnih predmeta sačuvani su do danas, dok se o izgledu i broju nekih može pretpostaviti zbrajajući opremu i niz predmeta koje možemo čitati iz raznih arhivskih spisa i oporuka. ${ }^{51} \mathrm{U}$ plemićke kuće unošene su raznolike rezbarene i najčešće oslikane umjetnine. Pokućstvo i pomodno posoblje bilo je umjetnički izrađeno, a u sobama su bili rezbareni vijenci, ukrašeni stropovi, stubišne ograde, vratnice nad ulazima i prozorska krila. Opskrbljenije kuće imale su klesane kamine. ${ }^{52}$ Prostori za rad i sobe za dokolicu bile su maštovito i bogato dekorirane te oblikovane u drvetu, što saznajemo iz ugovora koje su majstori sklapali s naručiocima, a u arhivskim spisima stoji i da su ornamentalno izdjeljane klupe, škrinje, kreveti, ormari i ostala stolarija, često još i oslikani. Na zidovima su visjele i zidne tapiserije i umjetničke slike, ${ }^{53}$ a u 18 . stoljeću neki su stropovi bili ukrašeni štukaturama. ${ }^{54}$

Razmatrajući navedene primjere može se zaključiti da kneževe palače nastaju kombiniranjem postojećih modela privatne izgradnje, s određenim modifikacijama s obzirom 
na funkcije. Kao kod oblikovanja prostornog rasporeda, tlocrtne sheme i vertikalne podjele unutar građevine, tako i kod oblikovanja pročelja, u slučaju ove vrste građevina susrećemo se s nizom uzora. I njihovo unutrašnje uređenje pokazuje neke sličnosti, no ne može se govoriti o čvrsto utvrđenim pravilima. Element koji na prvi pogled razlikuje i kneževe i privatne palače, a zapravo im je zajednički, ${ }^{55}$ jest to što detaljnije analizirajući ovu vrstu građevina možemo zaključiti da ipak nema doslovno iste, jedinstvene sheme, jer je svaka od njih rezultat rasta kroz stoljeća i nastaje prema mogućnostima i potrebama pojedine lokalne zajednice, odnosno obitelji u čijem je vlasništvu.

\section{Arhivski prilog}

DAZd. Katastri Dalmacije iz 17. i 18. stoljeća; fond br. 6. Catastici delle fabbriche di pubblica ragione esistenti nella provincia di Dalmazia et Albania eretti per comando del fu proveditor generale Angelo Memmo nell'anno 1789 - kutija 36: 121-122.

Catastico di tutte le Pubbliche Fabbriche esistenti nella Città di Sebenico, Scadrona e Territori adiacenti, le quali per ordine dell'Illustrissimo ed Eccelentissimo Signore Anzolo Memo Provveditore Gentile in Dalmazia, ed in vigore della premessa Terminazione dell E. Sua del di primo Maggio corrente vengono nel presente descritte, e marcate colle respettive denominazioni, uso, tempo di loro Errezione, o Generali Ristauri per quanto ha potuto rillevare da luoco per ossequiato Comando dell' E. S. l'infrascritto Uffiziale Ingegnere, dal quale rattifficata viene la descrizione d'ogni Fabbrica colla propria firma

Sebenico

No. 1 Nel Catastico in Venezia al 105.

Palazzo del N. H. Conte

Fabbrica di muro Coperta di Coppi, composta dall'unione di diverse Fabbriche.

Il Torrione

Il Palazzo con altra Fabbrica ad esso annessa

La Torretta e

La Forestaria

Il Torrion $\dot{e}_{-}{ }_{-}-\quad$ (ristauri annui - 1784/6)

Lungo _passi:_5_-4 ${ }_{--}$

Largo _passi: _ $7_{-} 4_{-}$

Alto _passi:_11___ 6

$\grave{E}$ diviso in quatro Piani, e il suo Pian terreno somministra due luoghi, l'uno contiguo allaltro, divisi da Muro ed un Andio che serve ad uso di Carcere.

Primo Piano in Soler somministra un luogo ad uso di Cancelleria Pretorea, ed uno ad uso di Carcere; non comunicano però fra loro.
Secondo piano in Soler

(ristauri annui - 1789.12 luglio come nel Foglio N.1. in Filza Giannicolò Nachich Ten.te Ingegnere)

somministra una sola Sala, che per mezzo di una porta comunica colla sala del Palazzo.

Terzo Pianno in soffitto somministra

un sol luogo ad uso di rippor legna ed altro.

La Fabbrica in ogni sua parte abbisogna di restauro, eccettuata la Carcere.

Palazzo

Somministra tre Piani, ed è

Lungo _passi:_22__-_

Largo _passi:_5 _- ${ }^{4}-{ }_{-}$

Alto _passi: _ 9

Il suo Pian Terreno Somministra un luogo ad uso di Tezzon per lartiglieria, ed il passaggio in Città con Porta, e di là della Porta fondo dei Conti Drago.

Sta pure contigue internamente Due Corti, divise da muro, con Porta di comunicazione nel mezzo.

Primo Piano in Soler somministra

Un lusco che serviva ad uso di Armamento, ed ora per Teatro.

Tre luoghi ad uso di prigione ad uno de quali si perviene per mezzo d'una scala di legno esterna, e per fine altre due Camere, una superior all'altra

Secondo Piano in Soler

Vi si ascende per mezzo d'una Scala di Pietra esteriore con poggi di legno, e picciolo Luoco di sotto ad uso di Prigionia somministra Una Sala

Una Camera d'Udienza, e

Due altre Camere Nobili.

Sopra questo Secondo Piano in soler evvi una soffita praticabile.

Dal palazzo si passa ad unialtra Fabbrica contigua

Lunga_passi:_ 7 _- -6

Larga _passi:_4_-_-6

Alta_passi:_5_-4 ${ }_{-} 6$

Il passagio dal Palazzo a questa Fabbrica stabilito sopra archi, somministra

Una Chiesetta

Un Porteghetto

Un Andio, ed

Una Cameretta

La sudetta Fabbrica ha tre piani,

il suo Pian Terreno somministra

Una Stalla

Una caneva, ed

Un terzo luogo ad uso di magazzeno per mezzo di una scala di legno con suo poggio, si và al

Primo Piano in Soler

Il quale somministra una saletta, e due camerini, l'ultimo di quali comunica con Altra picciola Camera posta sopra un'Arco, e per mezzo d'un altra scala di legno con poggio si và al

Secondo Piano in Soler,

il quale dà

Una Saletta, ed una Cucina

Finalmente una terza scala conduce da questo Piano in soffitta praticabile, che comunica con la soffitta contigua del Palazzo. 
Questa Fabbrica è in pessimo stato.

La Torretta è

Lunga _passi:_3_- $3_{--}$

Larga_passi:_1__4_6

Alta _passi:_5__3 3

Il suo Pian Terreno serve ad uso di Prigione, ed

Il Suo Pian in Soler che dà un sol luogo, con unica con la cucina, $e$

con la scala principal del Palazzo.

La sudetta Toretta è in cattivo stato.

\section{Forestaria}

Ha tre piani, ed è

Lunga _passi:_5 $5_{--} 3_{--}$

Larga _passi:_2 $2{ }_{-}^{4}--$

Alta _passi:_5 $5{ }_{-} 3_{-}$

Il Pian Terreno

Serve al uso di Tezzon

Il Primo Piano in Soler

Ad uso di Quartier per soldati della Guardia.

Secondo Piano in Soler

A questo piano conduce la scala principale, e somministra

Un andio, $e$

Due camere, alle quali ve ne sono altre due contigue, poste però

sopra un Pian Terreno di ragione privata.

Esteriorimente a questi lugohi vi è un Corridore con Coperto di

Coppi sostenuto da tre Colonne di pietra.

$\grave{E}$ in sufficente stato con mancanze.

Giannicolò Nachich Ten.te Ingenere

\section{BILJEŠKE}

1 Općenito o vremenu i karakteristikama mletačke vladavine na području istočne obale Jadrana vidi u: MAJA NOVAK, Sudstvo, državna uprava i gradnje u Mletačkoj Dalmaciji i Albaniji, Radovi Instituta Jugoslavenske akademije znanosti i umjetnosti u Zadru, 6-7 (1960.), 237-255; MAJA NOVAK, Autonomija dalmatinskih komuna pod Venecijom, Institut Jugoslavenske akademije znanosti i umjetnosti u Zadru, Zadar, 1965.; MARKO ŠUNJIĆ, Dalmacija u XV. stoljeću, Svjetlost, Sarajevo, 1967.; ŠIME PERIČIĆ, Dalmacija uoči pada Mletačke Republike, Sveučilišna naklada Liber, Zagreb, 1980.; TOMISLAV RAUKAR, Komunalna društva u Dalmaciji u XV. st. i prvoj polovini XVI. stoljeća, Historijski zbornik, 35 (1982.), 43-118; LOVORKA ČORALIĆ, Venecija - kraljica mora s lagunarnih sprudova, Meridijani, Samobor, 2004.; FREDERIC CHAPIN LANE, Povijest Mletačke Republike, Golden marketing - Tehnička knjiga, Zagreb, 2007.

2 Knezove, to jest upravitelje, imali su primjerice i Nin, Omiš i Brač, te poslije, nakon mletačkog oslobađanja od turske vlasti, Makarska i kontinentalni centri Knin, Sinj, Imotski i Klis. Upravno središte Brača bilo je u Nerežišćima gdje je bio i knežev dvor, no to se naselje nikada nije razvilo u gradski centar. Nin je pak dolaskom mletačke vlasti počeo propadati uslijed slabljenja njegove ekonomske moći, epidemije malarije, turskih osvajanja i iseljavanja plemića, a Omiš je u tom razdoblju funkcionirao kao vojno i pomorsko naselje, a ne urbani centar.

$3 \mathrm{U}$ razdoblju društvenog sazrijevanja istočnojadranskih gradova, od 12. do 14. stoljeća, svi se procesi usredotočuju na stvaranje komune i njezina ustrojstva. S time usporedno počinje i izgradnja sjedišta nove uprave, građevina u kojoj su i gradska vijeća i gradski knez imali prostor za svoj rad a i život. Tako u dalmatinskim gradovima kao jednu grupu u pravilu razlikujemo palače kneza i gradske palače (u tu su grupu uključene sve palače poznate kao i općinske, to jest municipalne ili komunalne), potom kao drugu grupu gradske vijećnice i kao treću gradske lože. Sve te građevine pripadaju arhitektonskom tipu javne palače koji je, kao predložak prostornog uobličavanja, nastao iz potrebe tijekom formiranja slobodne društvene organizacije dalmatinskih lokalnih sredina, a trajao je i kroz razdoblje mletačke uprave koja je nastavila, barem formalno i naravno uz određene modifikacije, koristiti postojeći vladajući model. Više o javnim palačama, definiciji pojma, nazivima, razvoju arhitektonskog tipa, pisanim izvorima, relevantnoj literaturi i sl. vidi u: ELENA SVALDUZ, Palazzi pubblici: i luoghi di governo e le sedi dell'amministrazione cittadina, Il Rinascimento Italiano e l'Europa, vol. 6. Luoghi, spazzi, architettura, (ur.) Donatella Calabi, Elena Svalduz, Fondazione Cassamarca-Angelo Colla Editore, Treviso-Costabissara (Vicenza), 2010., 125-158; KRASANKA MAJER JURIŠIĆ, Javne palače u Dalmaciji u vrijeme mletačke uprave, doktorski rad, Filozofski fakultet Sveučilišta, Zagreb, 2012., 11-30.

4 Takav je primjer i komunalna palača u Trogiru gdje se u drugoj polovini 13. stoljeća javila potreba za stalnim mjestom gdje bi se odvijale sjednice gradskog vijeća, nosioca vlasti u komunalnom društvu. Do tada su se sjednice održavale u katedrali: NADA KLAIĆ, Trogir $u$ srednjem vijeku: javni život grada i njegovih ljudi, Muzej grada Trogira, Trogir, 1985., 190

Upravo se zbog te potrebe organizirala gradnja komunalne palače u kojoj je bila i velika svečana dvorana za vijećanje, kao i druge prostorije koje su služile u javne svrhe. Ta je palača istodobno imala i ulogu stambenog objekta za kneza, sa svim pratećim sadržajima potrebnim u životu plemića. Uz palaču je sagrađena i loža namijenjena sudskim poslovima i raznim okupljanjima. U vrijeme prije izgradnje lože sudilo se u palači. Dokumentom iz 1302. godine gospodin knez i kapetan donosili su presudu u palači trogirske općine, sjedeći za sudskim stolom. IVAN LUČIĆ, Povijesna svjedočanstva o Trogiru, Čakavski sabor, Split, 1979., 355; IRENA BENYOVSKY, Trogirski trg u razvijenom srednjem vijeku, Povijesni prilozi, 16 (1997.), 11-33, 20. Tada je srednjovjekovna trogirska palača objedinjavala doista sve javne upravne funkcije, od smještaja i rada kneza, zasjedanja gradskog vijeća do suđenja.

5 U Splitu se javna palača u dokumentima navodi već od 1277. godine, mada se smatra da je bila sagrađena i mnogo prije, krajem prve polovine 13. stoljeća. Palača se nalazila na Peristilu, a u njezinu je prizemlju bila loža, dok su na katu vjerojatno bile dvorana za vijećanje i prostorije za stanovanje kneza. Kada se u prvoj polovini 14. stoljeća uređuje novi javni centar Splita, Trg sv. Lovre, svi se javni sadržaji tamo sele s Peristila. Godine 1368. godine u dokumentima nalazimo na tekst »in palati novo«, što navodi na zaključak da je tada nova komunalna palača već bila sagrađena. Dio toga građevinskog kompleksa, poslije poznatog kao kneževa palača, sazidan je vjerojatno tek sredinom 15. stoljeća i to na zapadnom dijelu sjeverne strane trga. O tome u: GRGA NOVAK, Gradski bedemi, javne zgrade i ulice u srednjevjekovnom Splitu, Starohrvatska prosvjeta, III (1952.), 107-109; CVITO FISKOVIĆ, Izgled splitskog Narodnog trga u prošlosti, Peristil, 1 (1954.), 71-102; DUŠKO KEČKEMET, Romanička loža u Splitu, Prilozi povijesti umjetnosti u Dalmaciji, 8 (1954.), 96-110; GRGA NOVAK, Povijest Splita II, Čakavski sabor, Split, 1978., 853; DUŠKO KEČKEMET, Rušenje Komunalne i Kneževe palače u Splitu, Godišnjak zaštite spomenika kulture Hrvatske, 4-5 (1978.-1979.), 287-302, 287; DUŠKO KEČKEMET, Vicko Andrić - arhitekt i konzervator, 1793-1866., Književni krug, Split, 1993., 29; RADOSLAV BUŽANČIĆ, Graditeljstvo Splita Marulićeva doba 1450.-1524., Split Marulićeva doba, katalog izložbe, (ur.) Goran Borčić, Muzej grada Splita, Split, 2001., 31-39.

6 Iznimka je kneževa palača u Hvaru za koju imamo sačuvan dokument od 3. travnja 1278. godine kojim se određuje gradnja kuće za hvarskog potestata Andreu de Molina ("providebitur... in domo etiam pro habitatione ipsius«), kao i još nekoliko dokumenata s kraja 13. stoljeća koji potvrđuju da je zgrada tada doista i sagrađena. REMIGIO BUČIĆ, $O$ javnim gradevinama i zgradama u Hvaru, Historijski arhiv, Hvar, 1956., 35; GRGA NOVAK, Hvar kroz stoljeća, JAZU, Zagreb, 1972., 159; IVO ŠTAMBUK, Razvoj Hvarske pjace, Hvarski zbornik, 4 (1976.), 261-280; AMBROZ TUDOR, Stambena arhitektura grada Hvara u 17. i 18. stoljeću, magistarski rad, Filozofski fakultet Sveučilišta, Zagreb, 1995., 30.

7 LARIS BORIĆ, Arhitektura i urbanizam grada Cresa od 1450.-1610. godine, magistarski rad, Filozofski fakultet Sveučilišta, Zagreb, 2002.

8 Nažalost, palača je srušena negdje nakon početka 19 . stoljeća, a o njezinu nam izgledu svjedoče tek slika grada Krka iz 1534. godine, 
rad Girolama Santa Croce, te dva kasnija opisa koji nam daju podatke o prostorijama u palači krajem mletačke uprave. Prvi opis je sastavio Ivan Feretić (1769.-1839.), a drugi Josip Antun Petris (1787.-1868.). Više u: SIMEON LJUBIĆ, Commissiones et relationes Venetae, sv. 1, JAZU, Zagreb, 1876., 29-101; IVAN ŽIC ROKOV, Gradske zidine i ulice u Krku, Krčki zbornik, 2 (1971.), 179-255; MARIJAN BRADANOVIĆ, Arhitektura i urbanizam renesanse na otoku Krku (knjiga I i II), doktorska disertacija, Filozofski fakultet Sveučilišta, Zadar, 2007.; KRASANKA MAJER JURIŠIĆ, Izgradnja i održavanje upravnih građevina u Krku od Vinciguerrine obnove iz godine 1489. do kraja 18. stoljeća, Godišnjak zaštite spomenika kulture Hrvatske, 35 (u tisku).

9 Najranije se spominje 1452. godine u uvodnom dijelu gradskog katastra: Državni arhiv u Zadru (dalje: DAZd), Katastri Dalmacije 17. i 18. stoljeća, br. 72. Cattastro di Pago, anno 1452. Ne može se sa sigurnošću reći da je tada palača već bila sagrađena, no svakako je postojala kao institucija. Iz dosadašnjih istraživanja poznato je pak da su sama zgrada i dvorišni trijem zasigurno bili dovršeni prije 1465. godine, dok su posljednji radovi na građevinskom sklopu palače izvedeni u vrijeme kneza Tome Zorzija (1466.-1469.) kada su izrađena dvorišna vrata i kruna bunara na kojima se nalazi njegov grb. MIROSLAV MONTANI, Juraj Dalmatinac njegov krug, JAZU, Zagreb, 1967., 47; EMIL HILJE, Spomenici srednjovjekovnog graditeljstva na Pagu, Arheološki muzej, Zadar, 1999., 109, 137; KRASANKA MAJER, Prilog poznavanju povijesti sklopa Kneževe palače u Pagu, Radovi Instituta za povijest umjetnosti, 32 (2008.), 139-150.

10 O ulozi generalnog providura za Dalmaciju i njegovu izboru stalnog sjedišta u: MAJA NOVAK, Zadar, glavni grad Mletačke Dalmacije i Albanije, Radovi Instituta Jugoslavenske akademije znanosti i umjetnosti u Zadru, 11-12 (1965.), 187-202, 192 i 194. O nekadašnjem izgledu providurove palače u Zadru detaljnije u: MARIJA STAGLIČIĆ, Izgradnja kneževe i providurove palače u Zadru, Radovi Filozofskog fakulteta u Zadru, 20 (1982.), 75-92; MARIJA STAGLIČIĆ, Gradevinska djelatnost u Zadru od pojave historicizma do 1. svjetskog rata (1868-1918), doktorska disertacija, Filozofski fakultet Sveučilišta, Zadar, 1983.; KRASANKA MAJER JURIŠIĆ, Zadarska providurova palača u vrijeme mletačke uprave, Povijesni prilozi, 44 (2013.), 183-202.

11 Zabilježeno je da 1706. godine javni inženjer Giuseppe D’Andre po službenoj dužnosti obilazi zadarsko zaleđe te u Novigradu i Obrovcu piše izvještaje o stanju kuća u kojima su bili smješteni državni predstavnici i potrebi njihove obnove. Isto tako, na uređenju javne palače u Novigradu bio je angažiran inženjer Francesco Melchiori koji je tijekom 1738. i 1739. godine radio i na popravku kneževe palače u Ninu. DARKA BILIĆ, Inženjeri i civilna arhitektura 18. stoljeća u mletačkoj Dalmaciji i Albaniji, doktorska disertacija, Filozofski fakultet Sveučilišta, Zagreb, 2010., 61.

12 KRASANKA MAJER JURIŠIĆ (bilj. 3, 2012.). Ista praksa nije bila zaseban slučaj ni u drugim pokrajinama pod mletačkom upravom. Tako se u Kotoru bilježi da se od potresa u 17. stoljeću pa sve do 1717. godine redovito unajmljuje privatna palača za potrebe mletačkog upravitelja. DAZd, Hitne obavijesti generalnih providura (Dispacci). Alvise Mocenigo 1717-1720, knjiga I: 283-285. Casa della famiglia Pasquali in Cattaro occupata all'uso pubblico: „... Scossa dal memorabile funesto terremoto nato per ? lanno 1667. tra l'altre Città di questa Superiore Provincia quella di Cattaro ebbe il dolore di veder sepolte le fabbriche sue migliori sotto alle proprie rovine. Il fatal colsso distrusse nel tempo medesimo il Pubblico Palazzo che serviva di decoroso ricovero agli Eccmi Provveditori Generali, alli Ilustrissimi Proveditori Ordinari ed Estraordinari, ed a N. N. H. H. Camerlenghi. La disgracia che lasciò senza allogio La Publica Rapprezentanza, condusse alcuni de citadini nel merito di somministrar loro a vicenda le proprie Case, sin a tanto che accorsavi con opportuni rispieghi la Pubblica providenza, fece rimettere a proprie spese le abitacioni agli Illustrissimi Proveditor Ordinario, $e$ Camerlengo. Rimasta però senza riparo quella parte che serviva alluso della carica Estraordinaria, fù la stessa accolta nelle case de particolari, e corrono trenta anni, da che senza interruzione alcuna s'attrova ella stabilita con fermo piede in quella delli g.mo Pima Nobili della Città predetta. Come la medesima ha portate con? di fidei comissaria sostitucione le ragioni dell' Eredità, e del privato Dominio ne Fratelli Pasquali del g.m Dottor Peppo cosi li stessi con divoto memoriale rassegnato al Regio Trono di Vostra Serenità, hanno umilmamente implorato nella liberazione della Casa pred.a il loro sollievo... Castel Novo 15. Novembre 1717.
13 U razmatranju tlocrtnih shema, kao i o tome koje su prostorije bile sastavni dio neke palače te gdje su se nalazile, pomažu nam arhivski dokumenti i neki od grafičkih prikaza, primjerice stare fotografije, vedute, akvareli, ali i nacrti izrađeni u vrijeme ili neposredno nakon mletačke vladavine u Dalmaciji. Detaljnije u: KRASANKA MAJER JURIŠIĆ (bilj. 3, 2012.).

14 Vidi bilj. 13.

15 Najraniji je nacrt Lorenza Vitelleschija (vidi: LORENZO VITELLESCHI, Povijesne i statističke bilješke o dubrovačkom okrugu - Dubrovnik 1827, (ur.) Vinicije B. Lupis, Matica Hrvatska Dubrovnik; Državni arhiv u Dubrovniku, Dubrovnik, 2002.; ALENA FAZINIĆ, Ponešto o javnom graditeljstvu 19. stoljeća u Korčuli, Godišnjak grada Korčule, 13 (2010.), 104-124, 108), zatim veliki tlocrt prizemlja i prvog kata cijelog kompleksa kneževa dvora koji je izradio Josip Zmajić (Nacrt je pohranjen u Gradskom muzeju Korčule. Zahvaljujem Mariji Hajdić koja mi je omogućila njegovo korištenje. Cvito Fisković ga prvi spominje u: CVITO FISKOVIĆ, Uz četiri nacrta Korčulanina Josipa Zmajića, Zbornik za likovne umetnosti, 18 (1982.), 215-241, 239. Vidi i: ALENA FAZINIĆ, Srednjovjekovne zidine grada Korčule, Radovi Instituta za povijest umjetnosti, 12-13 (1988.-1989.), 81-89), te treći, nacrt nepoznatog autora pod naslovom Ex palazzo del Conte con le adjacenti Opere Fortificarie nella Città di Curzola. Nacrt je iz sredine 19. stoljeća i također se nalazi u Gradskom muzeju Korčule, a navodi se u već spomenutim člancima: CVITO FISKOVIĆ (bilj. 15), 236; ALENA FAZINIĆ (bilj. 15, 1988.1989.), 88-89; ALENA FAZINIĆ (bilj. 15, 2010.), 109.

$16 \mathrm{U}$ tekstu se navodi da je to prikaz palače s pripadajućim dijelovima, koja je u vrijeme mletačke uprave služila za potrebe korčulanskog kneza. Nažalost, tekst je dosta izblijedio i teško je čitljiv.

17 BERISLAV KALOGJERA, Portret jednog grada na istočnom Jadranu, Matica Hrvatska, Korčula, 1995., 116.

18 NEVEN FAZINIĆ, Otok Korčula - popis otočkih župnih crkava, crkvi, crkvica, kapelica i špilja Gospe Lurdske, Godišnjak grada Korčule, 7 (2002.), 459-464, 464.

19 Katastar javnih zgrada, Catastico di tutte le Pubbliche Fabbriche esistenti nella Città di Sebenico, Scadrona e Territori adiacenti, izrađen je u vrijeme uprave generalnog providura Angela Memma 1789. godine. Dokument se nalazi u DAZd, Katastar za Dalmaciju - 18. stoljeće, Provveditore Generale Angelo Memmo IV (1786-1789): Catastico generale delle fabbriche tutte esistenti nelle piazze della Provincia della Dalmazia, a dio koji se odnosi na kneževu palaču u Šibeniku sastavio je mletački inženjer Gian Nicolò Nachich i nalazi se na stranicama 121-122. Vidi Arhivski prilog.

20 Nacrti su pohranjeni u Archivio di Stato di Venezia (dalje: ASVe). Sastoje se iz četiri table i datirani su 28. listopada 1778. godine (vjerojatno je pri pisanju došlo do pogreške jer je Zavoreo u Šibeniku boravio 1788.), u Šibeniku. Autor je Francesco Zavoreo, kapetan inženjer. Prva ih je predstavila javnosti D. Bilić, na znanstvenom skupu IX. dani Cvita Fiskovića 2008. godine u Orebiću, a obavljeni su u njezinoj doktorskoj disertaciji u sklopu prikaza djelovanja inženjera F. Zavorea. DARKA BILIĆ (bilj. 11).

21 Osim stubišta u Katastru se navodi da ovo krilo palače zapravo ima tri etaže (kuhinja i ostava zapravo su na trećoj etaži, a ispod njih su male prostorije: salon i dvije sobice) i tavan koji je prostran i povezan s tavanom iznad južnog krila.

22 ALBERTO RIZZI, Un satalogue raisonnè di leoni marciani in Dalmazia: Isola di Curzola, Prilozi povijesti umjetnosti u Dalmaciji (Petriciolijev zbornik II.), 36 (1996.), 153-175; GIUSEPPE PRAGA, Leoni di Traù, Archivio storico per la Dalmazia, anno VII, vol. XIV (1932.), 419-432. 23 Nedostaju podaci koji bi bili ključni za točnije određenje ove teze jer je teško donositi konačne zaključke na osnovi malobrojnih grafičkih prikaza pročelja srušenih palača u Cresu, Krku, Hvaru ili pak Splitu.

24 IVO BABIĆ, Renesansni lučni prozori i općinska palača u Trogiru, Adrias, 1 (1987.), 169-179; IVO BABIĆ, Kulturno blago Trogira, Turistički savez općine Trogir, Turistkomerc, Zagreb, 1990., 113-114. Ivo Babić u navedenom članku iz 1987. godine navodi i vjerojatnost da je prvotno sam N. Firentinac zamislio i izveo i balkon prvog kata (poslije uklonjen), a prema kojem je 1582. godine kod majstora Jakova Radojčevića zabilježena narudžba za isti takav balkon za kaštel Dujma Lipavića. Vidi također i: RADOSLAV BUŽANČIĆ, Nikola Ivanov Firentinac i trogirska renovatio urbis, Književni krug, Split, 2012., 107-116. 
25 Prvi atribuciju T. Bokaniću donosi CVITO FISKOVIĆ, Trifun Bokanić na Hvaru, Peristil, 16-17 (1973.-1974.), 53-64, 56. Također vidjeti: IVO BABIĆ (bilj. 24, 1987. i 1990.); RADOSLAV BUŽANČIĆ, Nikola Ivanov Firentinac. Arhitekt renesansne obnove Trogira krajem 15. stoljeća, doktorska disertacija, Arhitektonski fakultet Sveučilišta, Zagreb, 2008., 75; RADOSLAV BUŽANČIĆ, Trogirski i hvarski opus Trifuna Bokanića, Klesarstvo i graditeljstvo, 1-2 (2010.), 5-32, 17; ANA ŠVERKO, IVANA ŠVERKO, Projekt parternog uređenja glavnog trogirskog trga i karda iz polovice XIX. stoljeća, Klesarstvo i graditeljstvo, 1-2 (2010.), 69-83, 77; RADOSLAV BUŽANČIĆ (bilj. 24), 11 i 110-111.

26 MILJENKO DOMIJAN, Rab, grad umjetnosti, Barbat, Zagreb, 2001., 189; MILJENKO DOMIJAN, Rab u srednjem vijeku, Muzej hrvatskih arheoloških spomenika, Split, 2004., 63.

27 Balkon s balustradom i konzolama može se datirati u početak druge polovine 15. stoljeća i pripisuje se krugu majstora Petra Trogiranina (MILJENKO DOMIJAN, bilj. 26, 2001., 189) ili pak izravno njemu samome (MILAN PELC, Renesansa, Naklada Ljevak, Zagreb, 2007., 96). Lavlje glave kojima završavaju balkonske konzole nalik su na dekorativne konzole iz »Lavljeg dvora« $\mathrm{u}$ Senju, no nešto lošije izvedbe: MILAN PELC, Renesansa, Naklada Ljevak, Zagreb, 2007., 97.

28 MILAN PELC (bilj. 27), 98.

29 O portalu vidi: GIOVANNI SMIRICH, Il portale del palazzo del conte in Pago, Rivista dalmatica, vol. 1, fasc. 2 (1899.), 1-7; LJUBO KARAMAN, Eseji i članci, Matica Hrvatska, Zagreb, 1939., 62; MATE SUIĆ, Pag, uz 510tu obljetnicu osnutka Novog Paga, Paška općina, Zadar, 1953., 83-84. Prvi je Ivanu Pribislaviću ovaj rad pripisao CVITO FISKOVIĆ, Bilješke o paškim spomenicima, Ljetopis Jugoslavenske akademije znanosti i umjetnosti, 57 (1949.-1950.), 51-66, 62, a poslije su se tom mišljenju priklonili i drugi: RADOVAN IVANČEVIĆ, Reinterpretacija zborne crkve u Pagu, Peristil, 25 (1982.), 53-81, 73; IGOR FISKOVIĆ, Juraj Dalmatinac u Ankoni, Peristil, 27-28 (1984.-1985.), 93-146, 110; MILAN PELC (bilj. 27), 98.

30 REMIGIO BUČIĆ (bilj. 6), 36; GRGA NOVAK (bilj. 6), 163; AMBROZ TUDOR (bilj. 6), 30.

31 CVITO FISKOVIĆ (bilj. 25), 48, 49; ALENA FAZINIĆ (bilj. 15, 1988.-1989.), 82.

32 Ulomak kamina s grbom gradskog kneza Nikole Lauredana (1481.1484.) pokazuje da je u Rabu renesansa svojim ukrasima zavladala u devetom desetljeću 15. stoljeća. Detaljnije u: CVITO FISKOVIĆ, Prilog poznavanju kiparstva i graditeljstva 15. i 16. stoljeća u Rabu, Rapski zbornik. Zbornik radova sa Znanstvenog skupa o otoku Rabu, održanog od 25. do 27. listopada 1984. godine, (ur.) Andre Mohorovičić, JAZU, Zagreb, 1987., 321-332, 323.

33 VANJA KOVAČIĆ, Trogirske fortifikacije u 15. stoljeću, Prilozi povijesti umjetnosti u Dalmaciji, 37 (1997.-1998.), 109-134, 122; ANA PLOSNIĆ ŠKARIĆ, Gotička stambena arhitektura grada Trogira, doktorska disertacija, Filozofski fakultet Sveučilišta, Zagreb, 2010., 217.

$34 \mathrm{O}$ tome saznajemo iz opisa palače koji je sastavio J. A. Petris sredinom 19. stoljeća. Vidi bilj. 8.

35 MARIJAN BRADANOVIĆ, Šesterostrana kruna cisterne krčkog providura Angela Gradeniga, Prilozi povijesti umjetnosti u Dalmaciji, 40 (2004.), 239-254, 248; MARIJAN BRADANOVIĆ (bilj. 8), 16.

36 LARIS BORIĆ (bilj. 7), 49-50.

37 ĆIRIL METOD IVEKOVIĆ, Dalmatiens Architektur und Plastik, A. Schroll \& Co., Wien, 1910., 21; IVO DELLALE, Trogir - vodič po njegovoj historiji, umjetnosti i životu, Društvo za unapređenje turizma, Trogir, 1936., 15; IGOR FISKOVIĆ, Gotička kultura Trogira, Mogućnosti, 10-11 (1980.), 1036-1066, 1504; IVO BABIĆ (bilj. 24, 1990.), 113-114; STANKO PIPLOVIĆ, Graditeljstvo Trogira u 19. stoljeću, Književni krug, Split, 1996, 20; ANA PLOSNIĆ ŠKARIĆ (bilj. 33), 54.

38 RADOSLAV BUŽANČIĆ (bilj. 25, 2008.), 72. Isti autor navodi i mogućnost da je s Gojkovićem na palači radio i majstor Allegreto. Također i: RADOSLAV BUŽANČIĆ (bilj. 24), 108.

39 Prostori namijenjeni administraciji s druge su strane morali zadovoljavati potrebnu funkcionalnost manevriranja s mnogim spisima i njihovo je opremanje bilo s tim u skladu. I na kraju, prostori za suđenje morali su barem imati namještaj koji je omogućavao tijek suđenja: sudski stol za suce i klupe za prisutne.
40 Arhiv Hrvatske akademije znanosti i umjetnosti (HAZU), Kodeksi II c 43, vizitacija Petra Bemba (prijevod s latinskog Š. Demo).

41 Dokument je pohranjen u ASVe. Vidi detaljnije u: DARKA BILIĆ, Generalni inventar državnih građevina u Dalmaciji iz 1789., Radovi Instituta za povijest umjetnosti, 31 (2007.), 179-183.

42 KRASANKA MAJER JURIŠIĆ (bilj. 10).

$43 \mathrm{O}$ srednjovjekovnoj stambenoj izgradnji u Veneciji i mletačkoj Terrafermi vidi primjerice u: WART ARSLAN, Il gotico civile veneziano in Terraferma, Rivista dell'Istituo nazionale d'archeologia e storia dell'arte, n. s. XXIII-XXIV (1976.-1977.), 257-304; PAOLO MARETTO, Lédilizia gotica veneziana, Fillipi Editore, Venezia, 1978.; PAOLO MARETTO, La casa veneziana nella storia della città dalle origini allottocento, Marsilio Editori, Venezia, 1992.

44 NADA GRUJIĆ, Lédilizia civile sulla sponda orientale dell'Adriatico, Gotika v Sloveniji: nastajanje kulturnega prostora med Alpami, Panonijo in Jadranom. Akti mednarodnega simpozija, Ljubljana, Narodna galerija, 20.-22. oktober 1994, (ur.) Janez Höfler, Narodna galerija, Ljubljana, 1994., 403-411. Kuća jedinstvenog volumena karakteristična je za stanovanje nižega građanskog sloja. Nizovi malih kuća s jednom prostorijom na svakom katu, organizirani vertikalno tako da koriste što je manje moguć prostor unutar stisnute gradske jezgre, građeni su mahom tijekom ranoga srednjeg vijeka. Dimenzije tih jednoprostornih kuća predstavljaju modul parceliranoga urbanog tkiva. U 13. stoljeću započinje ujedinjavanje tih kuća tzv. elementarnog tipa i pojavljuje se tip velike kuće na parcelacijskom supstratu sitnije mreže. Uz te se velike zgrade često gradi vanjsko, najprije drveno a poslije isključivo kameno stubište, smješteno uz pročelje prema ulici ili u prostoru dvorišta, nadodanog uz postojeći objekt.

$45 \mathrm{O}$ srednjovjekovnom stambenom graditeljstvu u Trogiru vidi primjerice u: CVITO FISKOVIĆ, Romaničke kuće u Splitu i Trogiru, Starohrvatska prosvjeta, 2 (1952.), 129-178; IGOR FISKOVIĆ (bilj. 37); TOMISLAV MARASOVIĆ, Stambena kuća u Trogiru Radovanova doba, Majstor Radovan i njegovo doba: zbornik radova međunarodnog znanstvenog skupa održanog u Trogiru 26.-30. rujna 1990. godine, (ur.) Ivo Babić, Muzej grada, Trogir, 1994., 193-198; ANA PLOSNIĆ ŠKARIĆ (bilj. 33). Detaljnije o srednjovjekovnoj komunalnoj palači u Trogiru vidi u: ANA PLOSNIĆ ŠKARIĆ (bilj. 33), 52-53.

46 Odlike palača iz razdoblja kasne gotike i renesanse u Zadru su izgradnja dva kata, trijem u dvorištu, gospodarska uloga prizemlja, na katu je dvorana u koju se ulazi preko zatvorenog trijema, odvojeno su stambeni prostori. ANITA SABLJAK, PAVUŠA VEŽIĆ, Obnova kuće Nassis u Zadru, Godišnjak zaštite spomenika kulture Hrvatske, 4-5 (1978.-1979.), 155-179. $47 \mathrm{Na}$ splitskim primjerima privatne izgradnje u vrijeme gotike česta je primjena šiljastog luka, ostvarivanje reprezentativnosti kata na kojem se ostvaruje stanovanje dok prizemlje ima gospodarsku ulogu, te formiranje androne kroz koju se dolazi u prostor dvorišta. Također, D. Kečkemet povezuje kneževu palaču i susjednu zapadnu zgradu komunalne palače sa zgradama koje je J. Dalmatinac gradio u Splitu temeljem njihove karakteristične funkcionalno-građevne strukture i prepoznatljivog elementa vanjskoga kamenog stubišta. No, kako zgrade nisu sačuvane nije moguće izvesti detaljnu analizu mogućeg Jurjeva udjela u njihovoj gradnji. Vidi u: DUŠKO KEČKEMET (bilj. 5, 1978.-1979.), 287; DUŠKO KEČKEMET, Juraj Dalmatinac i gotička arhitektura u Splitu, Književni krug, Split, 1988., 11-15, 18-21, 50; DUŠKO KEČKEMET (bilj. 5, 1993.), 29; DUŠKO KEČKEMET, Kulturna i umjetnička baština Dalmacije, sv. 1, Marjan Tisak, Split, 2004., 125-127.

48 Tipično za šibensku stambenu arhitekturu je podizanje kuće u visinu. U kuću se vrlo često ulazi najprije kroz vrata u prostor obzidanog dvora te od tamo dalje u stambeni dio na katu stubama. JELKA PERIĆ, Kuća u Šibeniku od najstarijih vremena do konca XVIII. stoljeća, Radovi Instituta Jugoslavenske akademije znanosti i umjetnosti u Zadru, 2 (1955.), 233-264. 49 U sklopu javne palače u Trogiru, gdje je bio i stan kneza, bila je i kula u kojoj je bio stan za kancelara. Kula je ujedno bila i dijelom obrambenoga gradskog pojasa. IRENA BENYOVSKY, Popis javnih zgrada u Trogiru 1789. godine, Povijesni prilozi, 29 (2005.), 191-210.

$50 \mathrm{O}$ uređenju talijanskih palača vidi u: MARIO PRAZ, La filosofia dellarredamento, Longanesi \& C., Milano, 1964.; EVELYN WELCH, Art and society in Italy 1350-1500, Oxford University Press, Oxford, 1997., 
289-311; ELIZABETH CURRIE, Inside the renaissance house, V\&A Publications, London, 2006.; MARIO PRAZ, An illustrated history of interior decoration, Thames and Hudson, London, 2008., a o uređenju privatnih palača u Dalmaciji primjerice: JELKA PERIĆ (bilj. 48); IGOR FISKOVIĆ, Dalmatinski prostori i stari majstori, Književni krug, Split, 1990.; NEVENKA BEZIĆ BOŽANIĆ, Trogirski obrtnici od druge polovine 16. stoljeća do pada Mletačke Republike 1797. godine, Vartal, 2 (1993.), 109-125; NEVENKA BEZIĆ BOŽANIĆ, Prilog poznavanju zadarske kuće u 17. stoljeću, Prilozi povijesti umjetnosti u Dalmaciji (Petriciolijev zbornik II.), 36 (1998.), 273-287; NEVENKA BEZIĆ BOŽANIĆ, Majstori od IX do XIX stoljeća u Dalmaciji, Ministarstvo kulture RH, Konzervatorski odjel Split, Split, 1999.; ALENA FAZINIĆ, Neki podaci o privatnom životu u Korčuli od XVI. do početka XIX. stoljeća, Godišnjak grada Korčule, 9 (2004.), 67-106.

51 Oporuke članova plemićkih obitelji mnogo su puta vrlo koristan izvor informacija za rekonstrukciju života, opreme i namještaja kućanstava u prošlosti. ZDENKA JANEKOVIĆ-RÖMER, Rod $i \mathrm{grad}$. Dubrovačka obitelj od 13. do 15. stoljeća, Zavod za povijesne znanosti HAZU u Dubrovniku, Dubrovnik, 1994., 130. Primjerice, u oporuci Pavla Andreisa iz 1686. godine stoji cijeli popis pokretnina i opreme kuće u kojoj je on živio nakon očeve smrti. "Među kućnim predmetima, namještajem, posuđem i priborom bilo je od sasma običnog do umjetničkog: od drvenih nogara do raskošnog kreveta, od običnih dušeka, jastučnica i uzglavlja do plahta s ručnim vezenim radovima, od običnih do pozlaćenih stolova i izrezbarenih škrinja. Kuhinjski pribor je bio željezni, bakreni i mjedeni... a pribor za jelo je bio pored željeznog iskovan i u kositru i u srebru. U konobama bijahu tijeskovi za vino i bakrene `galede za njegovo mjerenje ... bačve, kamena pila i okrugle kamenice... neki sanduci ili škrinje bijahu izrezbarene u orahovini sall'anticas, od kojih je poneka bila ıvecchissimar, te je mogla pripadati gotičkom ili renesansnom slogu 15.-16. stoljeća. Stol za kojim se jelo bio je pokriven prostirkom, a postojali su i ubrusi za jelo. Stolovi izrađeni u orahovini ili u jelovini, bili su različite veličine...« Nabrajaju se dalje ormari s oslikanim vratnicama, drveni i željezni pozlaćeni kreveti, kao i oni iz lakiranog i pozlaćenog drva, sjedalice i klupe izrađene u orahovini i jelovini, također pozlaćene, svetačke slike od kojih su neke naslikane na drvu, zatim bakrorezi sa svetačkim likovima i prizorima, raspela od bjelokosti, križevi s mjedenim kandilima, zrcala, portreti članova obitelji, zidne zavjese, kožni zastori, čipkom ukrašena platna, željezni sanduk za čuvanje dragocjenosti, knjige, noćni ormarići u sobama i još mnogo toga. Zanimljivo je spomenuti kako Cvito Fisković spominje da u kući nije bilo oružja "mada se zna da ga je bilo u prošlim stoljećima u svakoj primorskoj kući«. CVITO FISKOVIĆ, Kuća povjesnika Pavla Andreisa u Trogiru, Historijski arhiv, Split, 1969., 217-227.

52 CVITO FISKOVIĆ, O starim dalmatinskim kaminima, Bulletin, 1 (1981.), 35-73.

53 Što se tiče slikarstva, važno je napomenuti da je nakon Blaža Jurjeva domaće slikarstvo zamrlo pa su u domovima plemića visjele slike iz uvoza. IVO BABIĆ, Renesansa u Trogiru, Dometi, 11 (1982.), 53-54. Najčešći motivi slika bile su svete osobe, pejzaži, biblijski i povijesni prizori. Na zidovima su znale biti i tapiserije, vrlo često izrađivane u našim gradovima, odnosno čak i u samim kućanstvima. Hanibal Lucić u jednoj svojoj pjesmi spominje i divi se umijeću Milice Koriolanović koja je u 16. stoljeću izrađivala tapiserije s prikazima krajolika: »... da ti si gospoja već neg sve ostale, umića ter tvoja usta te ne hvale, nu slava li glasi sama i povida, gospoje, svim da si gospojam naprida, i pravi da zlato i srebrom i svilicom, kad se stavi na to tva ruka s iglicom, mogu nam očito staviti prid oči što god jim skrovito tva misal potoči..." CVITO FISKOVIĆ, Stare tapiserije u Dalmaciji, Zbornik Muzeja primenjene umetnosti, 19-20 (1975.), 29-30.

54 RADOSLAV TOMIĆ, Štukaturist Giuseppe Monteventi - dijela, prijedlozi i hipoteze, Peristil, 44 (2001.), 81-92.

55 Dalmatinski primjeri javnih, odnosno kneževih palača, nisu jedinstvena i odvojena skupina, nego ih se treba razmatrati vezano uz ostale primjere upravne arhitekture izgrađene na područjima s kojima je $\mathrm{u}$ to vrijeme graditeljstvo u Dalmaciji moglo imati doticaja, u Istri, Primorju, Dubrovniku ili pak talijanskim pokrajinama koje su bile u sastavu Mletačke Republike. Detaljno o tome u: KRASANKA MAJER JURIŠIĆ (bilj. 3), poglavlje Razlikovno i povezujuće, regionalne karakteristike upravne arhitekture, 106-115.

\section{Summary}

Krasanka Majer Jurišić

The Dwellings of Venetian Rulers in Dalmatia from the 15th to 18th Century

The article presents the results of a study of the dwellings of the high Venetian administrators in the cities Cres, Krk, Rab, Pag, Hvar and Korčula on the islands of the same name, and in the Dalmatian cities on the mainland, Sibenik, Zadar, Split and Trogir, all of which were administrative centres in Dalmatia under Venetian rule. Analyzing the spatial organization, plans and the vertical arrangement of the interiors and the modelling of the fronts of the palaces occupied by the Venetian administrators (in English we call such a building the Rector's Palace) one can see that their styles derive from numerous sources. These palaces are combinations of existing models of private construction, modified in accordance with their function. These buildings clearly show the wish of their occupants to reflect and express the status and power of the Venetian administration. Generally speaking, one can conclude that in the 15th and 16th centuries most of these dwellings were the medieval regional "Rector's palaces" refurbished for Venetian use, but some new dwellings were also built. In the later period of Venetian domination, the 17th and 18th century, the same buildings underwent only repairs and refurbishment. 